\title{
Divergent Traditions, Converging Responses: Immigration and Integration Policy in the UK and Germany
}

\author{
SIMON GREEN
}

This article argues that although the UK and Germany have different historical traditions of immigration and integration, which continue to define policy responses in specific areas, recent developments show a distinct convergence in each country's policy goals and adopted policy instruments in this sector. The article contends that both endogenous (demographic and skills shortages, integration deficits) and exogenous (influx of asylum seekers, terrorism) variables can be identified for this convergence. It also pinpoints the European Union as a growing source both of convergence and policy coordination in this field.

\section{$\underline{\text { Introduction }}$}

In the context of this special issue on policy convergence in the UK and Germany, immigration and integration policy constitutes an obvious and in many ways ideal case study. There are three key reasons for this. First, for some decades now, both countries are two of the most significant destinations for immigration in the European Union (EU). In recent years, the two countries have received the highest volume of immigration and family reunification of all EU member-states, as well as granting the highest numbers of naturalisations; in absolute numbers of non-national residents, Germany and the UK are first and third respectively. Between 1998 and 2002, both countries took the top two places in the EU in terms of the number of asylum 
applications lodged; even since then, both remain near the top. ${ }^{1}$ Indeed, with the possible exception of France, no other EU member-state can match the UK and Germany for both the sheer scale and diversity of immigration they have received, as well as for the long period of time over which this immigration has taken place. Some key indicators of immigration to the UK and Germany between 2002 and 2005 are given in Table 1.

\section{Table 1 about here}

Second, and as will be elucidated below, both countries are facing broadly similar challenges in this field, including skills and demographic shortages and, perhaps most importantly, in the integration of their non-national / immigrant minorities, ${ }^{2}$ which has become a major political issue in Germany as well as the UK. ${ }^{3}$ The third reason for undertaking such a comparison lies in the politics of New Labour and the SPD-Green government, which came to power in the UK and Germany in May 1997 and October 1998 respectively. Several other contributions to this collection draw on the "Third Way' document, ${ }^{4}$ and although it makes no direct mention of immigration, both the Labour and the SPD-Green governments, upon assuming power, explicitly set out to 'modernise' immigration and citizenship policy from the essentially undifferentiated restrictive emphasis which had characterised the preceding conservative administrations. ${ }^{5}$

Together, this combination of common large scale immigration flows, similar challenges and the apparent ideological closeness of the two governments makes this 
area a prime example of where policy convergence might be expected. In this context, and drawing on Bennett's classification, ${ }^{6}$ it is helpful to distinguish between convergence of policy goals, which refers to the issues which are to be tackled, and of policy instruments, which for the purposes of this discussion will refer to the actual policies adopted to address the policy goals. This article will show that both these elements are visible in varying degrees across this policy field.

At the same time, what makes this convergence all the more remarkable is that it has occurred against the backdrop of very different historical traditions in each of the two countries. The importance of history and traditions for understanding current politics and policy is of course widely acknowledged in political science, and the resulting 'path dependence' of initial political compromises or institutional configurations can be defined thus: 'When a government programme or organisation embarks on a path there is an inertial tendency for those initial policy choices to persist. That path may be altered, but it requires a good deal of political pressure to produce that change'. ${ }^{7}$ In immigration and citizenship, as in several other areas covered in this collection, path dependence has been clearly identified by scholars in the cases of the UK and Germany. ${ }^{8}$

This article therefore begins by sketching out these historical traditions before examining a range of common pressures, both exogenous and endogenous, which has affected policy goals and instruments in the two countries. It also pinpoints membership of the EU and the gradual development of a common EU immigration policy as a key factor behind convergence in individual areas. The extent and nature of convergence is then discussed by drawing on examples from three main policy sub-fields: labour and dependant migration policy, integration and citizenship policy, and asylum policy. In 
addition, key exceptions to this pattern of convergence will also be outlined. In its conclusion, the article reviews the extent of convergence that has been identified and compares political and structural factors behind this.

\section{Historical traditions in immigration and integration policy}

One of the most striking factors of the convergence of policy is that where it has taken place in this field, it has occurred despite, and not because of, the very different prevailing traditions of immigration in both countries. And, as will be argued later on in this article, in those areas where endogenous and exogenous pressures have not produced a degree of convergence, path dependence remains a central explanatory factor of policy responses in the UK and Germany.

In the case of the UK, immigration and citizenship policy has been significantly influenced by the country's colonial past. ${ }^{9}$ Between the 1950 s and 1970 s, the vast majority of immigrants came from Commonwealth countries, primarily the Indian subcontinent and the Caribbean. Today, they constitute the majority of the immigrant population in the UK and its descendents, although there have been significant inflows of other nationalities since the late 1990s. These have occurred primarily via the asylum system, but also following the enlargement of the EU to central and eastern Europe in 2004.

Crucially, the fact that most immigration to the UK has been from Commonwealth countries has meant that access to citizenship, and in contrast to practically all other EU member-states, has been sidelined as a political issue. For under the British Nationality Act 1948, British citizenship (or more properly, subjecthood) was defined in a particularly expansive and inclusive way, which for all intents and purposes equated Commonwealth and British nationals. Nor has dual citizenship, which 
has been particularly controversial in Germany, ever been a political factor the UK. ${ }^{10}$ Indeed, the fact that the majority of the UK's non-EU residents (or Third Country Nationals - TCNs) are Commonwealth nationals, who already possess most citizenship rights including voting rights, furnishes them with an enormously privileged position vis-à-vis other immigrant groups.

What does of course set the British case aside from other European countries is the more formal issue of how residence rights were gradually detached from nationality during the second half of the twentieth century. ${ }^{11}$ Under the Commonwealth Immigrants Acts of 1962 and 1968, plus the Immigration Act 1971, access to residence in the UK was limited to 'patrials', or persons with direct family connections to the UK. This of course included most of the 'old' Commonwealth, specifically Australia, New Zealand and Canada, and excluded most people from 'new' Commonwealth countries such as India, Pakistan and Bangladesh. The situation was only partially resolved in the British Nationality Act (BNA) 1981, which drew a line under what had become the fallacy of a global Commonwealth subjecthood under the Crown, ${ }^{12}$ but in doing so created new subsets of lesser citizenships in the form of British Dependent Territories Citizenship (BDTC) and British Overseas Citizenship (BOC). It also marked a departure from the pure application of the territorial principle in the ascription of British citizenship at birth (ius soli), in favour of the principle of descent (ius sanguinis) supplemented by a qualified form of ius soli. Significantly though, and despite the clear tendency towards the restriction of the scope of British citizenship culminating in the BNA 1981, the UK retains one of the most liberal set of rules concerning the acquisition of citizenship in the EU. In the future, this is likely to ease significantly the legal incorporation of new immigrants, especially TCNs and refugees. 
The legacy of Commonwealth immigration has also affected a second area of difference between the UK and other EU member-states, namely its approach to integration. ${ }^{13}$ This has been based on the 'race relations' paradigm, in which an aspiration to strict immigration controls was combined with pragmatic and 'laissezfaire' integration. ${ }^{14}$ Throughout the second half of the twentieth century, the UK never attempted to pursue a joined-up integration policy; instead, its approach was characterised by the famous definition put forward by the then Home Secretary Roy Jenkins in a speech in 1966:

I do not think we need in this country a 'melting pot', which will turn everyone out in a common mould, as one of a series of carbon copies of someone's misplaced vision of the stereotyped Englishman ... I define integration, therefore, not as a flattening process of uniformity, but cultural diversity, coupled with equality of opportunity in an atmosphere of mutual tolerance. ${ }^{15}$

In practice, this meant that each immigrant community group was encouraged to cherish and foster its own minority ethnic identity (Jenkins' 'diversity'). At the same time, 'mutual tolerance' was enforced through some of the most comprehensive antidiscrimination legislation in the EU, in the form of the Race Relations Acts 1965, 1968 and $1976 .^{16}$

By contrast, Germany's historical legacy in immigration and integration policy can best be summarised by the statement 'Germany is not a country of immigration' (Deutschland ist kein Einwanderungsland), which punctuated government policy statements and documents throughout the 1970s, 1980s and up to the advent of the SPD-Green federal government in 1998. The rationale for this position dates back to the era of formalised labour recruitment (the so-called Gastarbeiter years), during which mainly young men were actively and formally recruited from Mediterranean countries, in particular Turkey, Italy and Yugoslavia, to come and work in West German factories 
and companies. ${ }^{17}$ Their employment and hence residence was never considered to be anything other than temporary, and for that reason, few efforts were made to structure or promote their integration. However, when the SPD-FDP government called a halt to organised labour migration in 1973 (the Anwerbestopp), the perspectives of the remaining Gastarbeiter were swiftly transformed from a hitherto temporary group into a more permanent minority. ${ }^{18}$ Accordingly, and against general expectations, the number of non-nationals in West Germany did not decrease after 1973 as the remaining temporary workers returned home: on the contrary, numbers increased due to new migration for the purposes of family reunification. Consequently, such secondary migration itself quickly became a policy priority in terms of restriction and actively divided the main parties for much of the 1980s and, to a lesser extent, the 1990s.

This migration alone would have justified rethinking the paradigm of the nonimmigration country. But further large-scale primary immigration arose from the late 1970s onwards in the form of asylum seekers, and has continued ever since. Indeed, at its peak between 1990 and 1993, over 1.2 million persons claimed asylum in Germany. Furthermore, (West) Germany has also been the destination for one of the world's largest ethnic migrations, with over 4 million ethnic Germans, mainly from Poland, Romania and most recently the former Soviet Union, arriving between 1950 and 2004. Their right of entry was originally enshrined in the 1953 Refugees and Expellees' Law (Bundesvertriebenen- und Flüchtlingsgesetz), which, in a remarkable example of path dependence, continued until the end of the Cold War, when sharply rising numbers of arrivals rendered this entry mode unsustainable. Even now, any ethnic German born before 1993 can apply to be recognised as such, which, as well as right of entry to 
Germany, brings with it automatic citizenship and still comparatively generous help with linguistic, social and economic integration into German society. ${ }^{19}$

As early as 1980, this accumulation of immigration flows had transformed most large West German cities into permanent multi-ethnic, culturally pluralist spaces. Yet the political adjustment to this fundamentally changed reality has been slow. ${ }^{20}$ The possibilities of permanent residence remained highly restrictive, and it was a decision by the Federal Constitutional Court in 1978, not a change in government policy, which opened up this avenue in the first place. ${ }^{21}$ In particular, citizenship remained an elusive status, with no provision for ius soli at all, combined with very high requirements for naturalisation, including long periods of residence, eye-watering fee levels, a high degree of 'integration' (or more properly, assimilation) into German culture and a rejection of dual nationality. ${ }^{22}$ This also reflected the prevailing political view of integration, which, for instance in the debate over Leitkultur (or 'guiding culture') of $2000,{ }^{23}$ has consistently emphasised the duty of non-nationals in Germany to adapt to indigenous values, in whatever way these are defined. Indeed, until 1998 it was explicit government policy that naturalisation could only occur at the end of a successful integrative process, and not be considered a stepping stone towards this ultimate goal.

Moreover, despite the extent of immigration to West Germany, it was considered politically impossible to reform citizenship as long as the country remained divided. In an explicit attempt to undermine the German Democratic Republic (GDR), (West) Germany deliberately maintained Imperial Germany's 1913 citizenship law as the basis for its citizenship, since the law's pan-Germanic focus by definition included the citizens of the GDR. ${ }^{24}$ Here too, then, the dynamics of path dependence are in evidence: it was not until 1999, almost ten years after unification and only once the government 
had changed, that enough political momentum could be generated to pass a new citizenship law at all. ${ }^{25}$ Although the new law's provisions have meant some liberalisation, in particular through the introduction of partial ius soli, its overall impact has been much less than expected. ${ }^{26}$ In consequence, access to full citizenship in Germany remains, even today, the exception rather than the rule.

Certainly, the historical traditions in the UK and Germany show considerable differences in the way the two countries have approached immigration and integration. Although both countries have emphasised their desire to restrict new immigration since the 1970s, the UK has generally been more relaxed about its status as a country of immigration than Germany. At the same time, that is not to say that immigration and 'race' have not been passionately contested issues in Britain - witness for instance the Notting Hill riots in 1958, the notorious 1964 election campaign in Smethwick, ${ }^{27}$ Enoch Powell's apocalyptic 1968 vision of violent ethnic conflict, the Brixton riots of 1981 and the 1997 Macpherson report into institutional racism in the Metropolitan police.

By contrast, Germany has only recently begun to acknowledge that it is an ethnically and culturally diverse society. Indeed, the extent to which this is the case has only become clear in the last years: in 2005, the Mikrozensus revealed that over 15 million people in Germany, or almost one in five inhabitants, had some form of migrant background. ${ }^{28}$ Much of this gradual transformation can be traced back to unification. This not only unleashed unprecedented migratory forces in the form of asylum seekers and ethnic Germans, but also rendered void one of the defining purposes of West Germany's citizenship policy: the undermining of the GDR. ${ }^{29}$ Even so, the distinction between 'Germans' and 'others' remains largely intact, as illustrated by the party political focus on the perceived unwillingness of existing non-nationals 
(Bestandsausländer) to integrate into German society. In the UK, Tony Blair did make a similar call on immigrants to conform in a speech on 8 December 2006, but this was generally directed at new, not existing, communities - a fine but important distinction. ${ }^{30}$

As the remainder of this article will go on to show, these broadly different starting points have nonetheless led to policy convergence in a number of areas, although some significant differences inevitably remain. Where convergence has taken place, it has done so as a result of a number of pressures, and it is to these that this article now turns.

\section{Pressures towards convergence}

The pressures towards policy convergence in the UK and Germany can broadly be categorised under two headings: exogenous and endogenous pressures. In turn, under the rubric of exogenous pressures, two principal forces can be identified: asylum seekers and terrorism. Certainly, asylum is not a new political issue in Germany. As Figure 1 shows, (West) Germany has accepted large numbers of asylum seekers ever since 1980. Indeed, during the 1980s and early 1990s, asylum within the EU was in effect a purely (West) German problem, as anything up to two-thirds of annual applications to EU-15 countries were made in Germany.

\section{Figure 1 about here}

But Figure 1 also shows that, following the constitutional changes in 1993, the numbers of asylum seekers to Germany began to drop off; indeed, in 2004, just 35,000 applications were made in Germany, the lowest level for twenty years. Of course, the pressures for asylum themselves did not disappear (witness the rising number of total 
applications to the EU-15 from 1996 to 2002). Instead, applications were spread over a larger number of countries and, for the first time, asylum was no longer a de facto German problem.

In the first instance, it was in fact the UK which replaced Germany as the EU's primary destination for asylum seekers. ${ }^{31}$ In 2000 , the UK exceeded Germany's total asylum applications for the first time, and it has continued to do so in subsequent years too. From 2000 to 2003, the UK was in fact the largest destination for asylum applications in the EU, although it was overtaken in 2004 by France. However, it must also be noted that the scale of asylum applications to the UK at all times remained far lower than in Germany during the early 1990s: even at their peak in 2002, the number of asylum seekers to the UK was lower than the 107,000 applications lodged in West Germany as early as 1980 . But crucially, the increase in numbers has raised much the same kinds of policy questions in the UK as it has done in Germany, as the existing 'liberal universalist' model of asylum has came under severe pressure. ${ }^{32}$ It also opened up the possibility of both countries co-operating together in context of the EU to achieve EU-wide solutions, a point which will be returned to below.

The second key exogenous pressure, which has also taken on an endogenous dimension, especially in Britain, has been that of security generally, and terrorism more specifically. Although in both countries there has always been an internal security dimension to migration policy, this has taken on a much more dominant role in the aftermath of the terrorist attacks on New York and Washington DC on 11 September 2001, and the subsequent suicide bombings in London in July $2005 .{ }^{33}$ Both countries have considered themselves in the front line against (radical Islamic) terrorism, due not only to the fact that both have large Muslim populations, but also because a 
considerable number of Islamic fundamentalists, such as the cleric Abu Hamza and Metin Kaplan were granted asylum or settled in Britain and Germany respectively after fleeing political persecution in their home countries. Unsurprisingly, following the suicide bombings in London in July 2005, this issue has been more explicit in the UK than in Germany. Overall, the spectre of terrorism has contributed both to the explicit 'securitisation' of immigration policy, especially at EU-level, ${ }^{34}$ as well as to a renewed emphasis on assimilatory elements of integration and citizenship, as the discussion below will argue. ${ }^{35}$

These two major exogenous pressures towards convergence are complemented by two further endogenous factors: demographic and skills shortages, and the persistence of apparent structural deficits in the integration of immigrants and non-nationals. Demographically, both countries are about to feel the full impact of long-term shifts in population structures, in particular the sharp reduction in the fertility rate most European countries have experienced at various stages since the early 1970s. In 2004, Germany's fertility rate was just 1.4 children per woman; in the UK, it was 1.8 - better, but nowhere near the 2.2 level needed for population stability. ${ }^{36}$ What is more, this reduction in the number of children born in the UK and Germany has combined with increasing life expectancies to multiply the deleterious impact on support ratios between those of working age (15-64) and the remainder of the population. In this context, the UN Population Division in 2000 famously, albeit rather crudely, calculated that the number of immigrants required by the UK and Germany 2050 to keep support ratios at their 1995 levels, about 4:1 in both countries, was 1 million and 3.4 million respectively per annum. ${ }^{37}$ Certainly, (non-EU) immigration is by itself not a viable solution to such structural developments, as immigrants of working age are destined to retire from the 
labour market themselves at a future stage. But tellingly, the Office of National Statistics' prediction that the UK population will grow to 67 million by 2031 is largely predicated on continuing net immigration. By contrast, Germany's population is predicted to fall to around 73 million in 2050 despite assumed net immigration of 200,000 persons per annum. ${ }^{38}$

The UK and Germany's demographic problems are complicated by persistent skills shortages in key areas of the economy. In the UK, the Learning and Skills Council identified some 679,000 vacancies in the UK economy for 2003, principally in health and social work, business services and hotels and catering. ${ }^{39}$ In Germany too, skills shortages have persisted despite high levels of unemployment, with a survey of employers showing acute shortfalls in the pharmaceutical, engineering and information technology sectors. ${ }^{40}$ Together, this combination of skills and demographic shortages has created strong pressure in both countries, especially from business interests, in favour of a more relaxed approach to labour migration.

The second endogenous factor towards convergence has been growing concerns about integration outcomes. In both countries, migrants and their descendants are, generally speaking, more likely than the indigenous population to suffer from lower educational outcomes, lower incomes and lower language skills. ${ }^{41}$ In particular, their unemployment rates are often double those of the population as a whole. ${ }^{42}$ Significantly, these integration problems are not spread equally across national or ethnic groups: in the UK, Pakistanis and Bangladeshis are particularly disadvantaged in terms of education and labour market outcomes, while in Germany, Turkish and ex-Yugoslav nationals are the most affected. Notably, ethnic German immigrants, who have already been granted citizenship on entry to the country, display strikingly similar patterns of exclusion to the 
non-national population. Overall, both countries are grappling with comparable problems of social cohesion within and between their respective immigrant and nonnational communities.

One further pressure towards convergence needs to be considered at this point: the European Union. Over the past 15 years the EU's influence in this field has grown exponentially: its immigration policy has evolved from 'loose intergovernmental cooperation to a partially communitarised policy-making area' under the 1997 Treaty of Amsterdam, with an explicit aspiration of developing a common asylum policy for all EU member-states. ${ }^{43}$ Certainly, the process of 'Europeanisation' in this particular field is multifaceted, encompassing both the framing of issues and their governance, both of which have generated a rich body of academic literature ${ }^{44}$ the resulting implications of Europeanisation for policy convergence more generally are also discussed in greater detail in the Introduction and in Simon Bulmer's contribution to this collection. But essentially, Europeanisation can be considered to consist of both the 'uploading' of national policy preferences into the supranational policy-making process, and the 'downloading' of EU policy into the national policy arena, and it is these aspects which, within the spatial limitations of this article, will be the primary focus here.

Yet despite setting the goal of a common immigration and asylum policy, as well as its affirmation in the European Council meetings at Tampere in 1999 and at The Hague in 2004, progress towards fulfilling it has been painstakingly slow, for several reasons. For one thing, EU member-states' interests are quite heterogeneous in this area. Although pressures of numbers in asylum now affect most European countries, they do not do so equally - of EU-15 states, Italy, Portugal and Spain all received less than 1 asylum application per 1,000 inhabitants during 2001-5, compared with 3.3 for 
Germany and 5.5 for the UK. ${ }^{45}$ Second, because immigration is a classic 'high politics' area, concerns over loss of sovereignty are also clearly visible in this sector - witness the UK's refusal to participate in the communitisation of the Schengen Accord on border controls under the Treaty of Amsterdam, as well as in the EU's common visa policy. Lastly, the bar for achieving a communitised policy is set higher in this policy field than in others: whereas the single market can operate according to the principle of 'mutual recognition' of standards and norms, a common immigration area cannot do so, and therefore requires full-scale harmonisation. Unsurprisingly, and given the first two factors, this has been difficult to achieve. ${ }^{46}$ Key directives in this field on family reunification, asylum and the status of long-term resident third country nationals have only been agreed after literally years of negotiations. ${ }^{47}$ Collectively, it can be argued that such Directives have established something approaching an EU-wide immigration policy. Even so, in order to achieve agreement between member-states, they have in part fallen back on principles such as mutual recognition, for instance in the conditions for granting long-term residence status to TCNs, as well as, in the case of family reunification, so-called EU-wide 'minimum standards' ${ }^{48}$ The extent to which the EU's immigration policy can be considered to be harmonised fully thus remains very much open to debate.

Nonetheless, the UK and Germany have both at different times been keen to use the EU in order to find solutions to their own national problems. During the height of asylum applications to Germany in the early 1990s, the CDU/CSU-FDP government under Helmut Kohl made it a political priority to seek an EU-wide asylum policy. However, given the widespread opposition to this from other, less-affected memberstates, Germany had to content itself with the inclusion of asylum and immigration 
under the intergovernmental 'third pillar' under the 1992 Treaty of Maastricht. ${ }^{49}$ Subsequently, the government reverted to a domestic solution in the form of the 1993 constitutional amendments, after which Germany became much less willing to support integration at all costs. This trend increased as it became apparent that the European Commission was pursuing a somewhat more liberal line on asylum than Germany was prepared to countenance. ${ }^{50}$

Similarly, the UK's discovery of the European arena coincided with the peak in its asylum applications between 2000 and $2003 .{ }^{51}$ Despite having secured the possibility to 'opt-in' to this area under the Treaty of Amsterdam, the UK signed up to all seven measures on asylum adopted by the EU between 1999 and 2004. Andrew Geddes therefore concludes that 'Britain has thus become a little more European in its migration management policies in the hope that Europe will become a little more British in terms of convergent policy preferences'. ${ }^{52}$ At the same time, both countries also use their EU membership as a forum for informal coordination. Along with France, Italy and Spain and Poland, both are members of the so-called 'G6' group of large member-states, whose regular meetings, including in this policy area, have served as an informal forum for the coordination of policies and actions.

\section{Convergence and non-convergence in policy agendas and responses}

This, then, is the historical and topical background against which policy convergence can be considered. And indeed, it is apparent that some convergence in policy goals, both domestic and European, as well as to some extent in actual policy instruments adopted, has taken place between the two countries, even though divergence persists in other areas. Without claiming to be exhaustive, especially with reference to EU initiatives, the following section draws on a range of examples from the 
domestic and supranational arenas to illustrate this argument. It is subdivided into three substantive areas, each of which illustrates increasing levels of convergence: labour and dependant migration, citizenship and integration policy, and asylum policy.

\section{Labour and dependant migration}

Initially, labour migration represented one of the core elements of the process of modernisation in immigration policy which New Labour and the SPD-Green governments aspired to. Instead of maintaining their predecessors' ultimately undeliverable promises to prevent (non-ethnic) immigration altogether, ${ }^{53}$ the centre-left governments in the UK and Germany resolved instead to structure migration to the respective countries' advantage. This change in perspective coincided not only with demographic and skills issues returning to the fore, but also with the boom of the 'New Economy', with its seemingly insatiable demand for new ideas and skills in information technology. And it was this sector which proved to be the catalyst to new labour migration in both countries. ${ }^{54}$ In February 2000, Chancellor Schröder, to widespread acclaim from business leaders, announced the introduction of the so-called 'Green Card' scheme, under which up to 20,000 IT specialists would be allowed to work for up to five years in Germany. Despite its limited scope, this proposal helped redefine the terms of the debate, by emphasising for the first time in almost 30 years that immigration could actually benefit Germany. ${ }^{55}$ This principle was carried forward in 2001 into the discussion over the form a possible comprehensive immigration law (Zuwanderungsgesetz), the first in Germany's history, might take. The so-called Süssmuth Commission, which was set up by Interior Minister Otto Schily to develop reform proposals, even suggested a points-based system to attract an annual quota of high-skilled migrants, plus additional migration in shortage sectors. ${ }^{56}$ 
In the end, though, the Commission's recommendations proved too radical a change in political terms. Faced with an electorate which remained deeply sceptical about immigration, not least in times of record unemployment, the opposition CDU/CSU dropped its initial support for the government. Ultimately, the new law, which did not come into force until 1 January 2005, failed to go beyond providing limited entry possibilities to individual high-skilled migrants from outside the EU. Tellingly, the Green Card programme itself proved not to be a great draw either: not even the initial, distinctly modest quota could be fulfilled. ${ }^{57}$ What is more, holders of Green Cards quickly came up against ingrained administrative patterns of implementation, which continued to view their very presence as undesirable. ${ }^{58}$ Yet despite such setbacks, the issue of new labour migration remains very much on the political agenda and during 2006, the CDU/CSU-SPD Grand Coalition began to explore once more the possibility of introducing a points-based entry system for high-skilled migrants. ${ }^{59}$

In the UK, the policy response to demographic and skills shortages was similar, although it went much further than in Germany. In contrast to its German counterpart, the Home Office from the outset went on the offensive in terms of framing labour migration, both skilled and unskilled, as indispensable to the UK economy; crucially, and in direct contrast to Germany, it met with little resistance, due no doubt also to the continued buoyant economic situation in Britain. ${ }^{60}$ Thus in early 2002, the UK government introduced the Highly Skilled Migrants Programme (HSMP), which aimed to attract non-EU professionals, principally in finance, information technology and medical services, and which sat alongside a range of entry schemes for both high-skilled and lesser skilled migrants. ${ }^{61}$ But in the UK too, the HSMP has not been seen as a 
success, due to its cumbersome process and perceived inflexibility. ${ }^{62}$ Since then, the UK government, in its five-year strategy for migration published in 2005, has outlined plans to consolidate all existing entry schemes into a single, points-based system of recruitment. $^{63}$

In labour migration, then, there has been a certain degree of convergence around the overall policy goal of facilitating the immigration of skilled labour. There has also been convergence around the policy instruments for facilitating such migration, in the form of a points system. That said, the UK has been prepared to countenance a much wider definition of labour migration than Germany, to include lower and even unskilled migrants. Clearly, along with more favourable public opinion, the strength of the UK labour market compared to Germany's (see the contribution by Funk to this collection) is a major factor behind the UK's hitherto more liberal approach.

Indeed, this constitutes the principal dimension of divergence between the two countries, which became most clearly visible in their responses to the 2004 accession of eight central and eastern European countries to the EU. Germany, together with Austria, imposed a seven-year delay in the implementation of free movement of labour for these states, whereas the UK, Ireland and Sweden opened their labour markets immediately. However, despite its restrictions, Germany has been grappling with formally selfemployed tile-layers and abattoir workers from accession states undercutting existing labour. Even the UK government has been taken by surprise by the extent of labour migration from these countries: between May 2004 and June 2006, a total of almost 447,000 workers, mainly from Poland, were registered in the UK. ${ }^{64}$ This has been far more than the government originally estimated and has prompted the Home Office to 
limit access to the UK labour market to self-employed workers from Bulgaria and Romania following these countries' accession on 1 January 2007.

Dependant migration constitutes a further area of divergence in both policy goals and instruments between the UK and Germany. ${ }^{65}$ In Germany, this has been one of the most protracted areas of dispute in immigration policy, and the subject of party conflict since the early 1980s. The single most recurrent issue has been the age limit for children to immigrate to join their parents, which has been set at 16 since 1981 , but which the CDU/CSU has periodically attempted to lower to 12 , ten or even six. By contrast, although family reunification has been recognised as an important issue, it has rarely been politicised in the same way as in Germany, and certainly not around the same totemic issue. Indeed, when the 2003 Directive on Family Reunification set a minimum age of twelve for any limitation of the immigration of dependant minors, this represented a direct 'uploading' of the debate at that time in Germany (which was being held in the context of the discussions over the Zuwanderungsgesetz); other memberstates could of course choose to diverge upwards in setting this limit. In the UK, by contrast, family reunification has never been as polarised as in Germany; indeed, the UK chose not to opt in to the EU Directive. Here, then, is a further example of the power of path dependence: because the German discussion about family reunification has been framed for over 20 years around the specific issue of the maximum age of dependant minors, this not only continues to affect contemporary policy-making (witness the discussions about the Zuwanderungsgesetz between 2000 and 2004), ${ }^{66}$ but has even shaped policy instruments for the EU as a whole.

\section{Citizenship and integration policy}


The second area where policy convergence can be identified is in citizenship and integration policy. As was noted above, this policy area has grown in importance within this sector as a result of the persistence of structural integration problems in both countries. An additional catalyst in this respect has also been the impact of 9/11, which has not only moved security considerations into the spotlight, but also raised public expectations of immigrants to identify actively with, and to assimilate more explicitly into, their countries of residence. ${ }^{67}$ This convergence in policy agendas has generated specific convergence in three principal areas.

First, the formal provisions for naturalisation are converging, not only in the UK and Germany but also across other EU member-states. ${ }^{68}$ Indeed, the direction of convergence is interesting: whereas Germany, like most other EU countries, has tended to liberalise its citizenship provisions during the 1990s, the British Nationality Act 1981 actually represented a restriction. In both cases, this can be put down to respective historical traditions: thus, Germany started from an almost completely exclusive position in the 1970s, while the main policy challenge for the UK during the 1960s and 1970s was to manage the retreat from the expansive definitions of the British Nationality Act 1948. But certainly, a degree of convergence is crystallising in citizenship policy, with both countries employing a mixture of ius soli and ius sanguinis in the ascription of citizenship at birth, and both countries as a rule requiring between five and ten years' residence for naturalisation.

Second, these baseline requirements have been supplemented in recent years by additional criteria aimed at raising the symbolic value of obtaining British and German citizenship. In the Nationality, Immigration and Asylum Act 2002, the UK introduced both citizenship tests and ceremonies, which themselves drew heavily on the practises 
of countries such as Canada and Australia. ${ }^{69}$ Germany followed suit in mid-2006, with the Länder collectively agreeing on the inclusion and organisation of naturalisation tests and a formal ceremony, both of which had hitherto been implemented only on an ad hoc basis. $^{70}$

In fact, the introduction of integration courses and tests generally is emerging as an area of convergence between the two countries. However, this was not always the case. In Germany, the 2004 Zuwanderungsgesetz linked integration and language classes explicitly to permanent residence and not nationality, while the opposite was true for the UK. Now, not only is Germany making naturalisations subject to tests, but in his speech of 8 December 2006 Tony Blair also announced that the UK would introduce a language requirement for permanent residence. ${ }^{71}$ Even though the two countries' respective philosophies of integration persist (see above), it is clear, therefore, that integration policy as structured by government is starting to show distinct signs of convergence. Significantly, this convergence is not limited to the UK and Germany, but encompasses other member-states too. ${ }^{72}$

Third, following the inclusion of an anti-discrimination provision in Article 13 of the Treaty of Amsterdam, which came into force in 1999, a Racial Equality Directive and an Employment Equality Directive were passed only one year later in $2000 .^{73}$ Of these, the content and aims of the former bears close resemblance to the UK model of race relations legislation (see above). At first sight, this therefore appears to be a clear example of an 'uploading' to the EU and subsequent diffusion to other EU memberstates of existing UK norms and practises. But as Andrew Geddes and Virginie Guiraudon show in a fascinating study, the full picture is more complex. ${ }^{74}$ They argue that the very adoption of Article 13 at Amsterdam was contingent on the victory of 
centre-left governments in both France and the UK in early 1997, both of which, albeit for different reasons, favoured its inclusion in the Treaty. Furthermore, the SPD-Green government in Germany, having won the 1998 federal election, then also committed itself to formulating Germany's first anti-discrimination law in its subsequent coalition agreement. $^{75}$ This meant that when the European Commission tabled the first draft of the Race Equality Directive in late 1999, the broad policy goals of the governments of three key EU member-states had already converged, although this was due less to ideological factors than to an independent alignment of national positions. However, ideology did come into play in the adoption of the policy instrument in the form of the Directive itself, which was completed by June 2000, just seven months after being introduced. Although Geddes and Guiraudon also acknowledge the role of the Portuguese Presidency in this process, they pinpoint one factor in particular: the formation of the new Austrian government in early 2000 to include the extremist Freedom Party under Jörg Haider. This prompted other member-states, mainly with centre-left governments, to back this Directive, even in cases when, as in France and Germany, the country's traditional interpretation of the role of anti-discrimination legislation did not match with the focus of the policy instrument. ${ }^{76}$ The Directive was finally transposed into German national law during 2006.

The case of the Race Equality Directive highlights how convergence in policy instruments can occur. Certainly, the EU played an indispensable role in this; but at the same time, the independent convergence of national positions was a vital precondition for the success of the Commission's initiative. ${ }^{77}$ Interestingly, the question of an ideological convergence of governments appears only to have played a subsidiary role, principally in determining the response to Austria's new government. Yet in this area, 
the Directive arguably represents the start of convergence, not its conclusion, as both national courts and the European Court of Justice are likely to guide its implementation.

Even so, areas of divergence remain in citizenship and integration policy, and they are areas in which the historical legacies in both countries are arguably most clearly visible. First, there is clear divergence in the status of nationality as a policy goal. In the $\mathrm{UK}$, as noted above, the acquisition of nationality is not politically contested in any real way. This is due also to the fact that the UK's (Commonwealth) immigrants already possess voting rights, which is itself a clear historical legacy and one which affects the structure of British Citizenship in a path dependent fashion. In Germany, by contrast, the incorporation of non-nationals, over 20 per cent of which were actually born in Germany, has continued to be sluggish. Correspondingly, access to citizenship rights remains a substantive political issue which is hotly contested, not least for electoral reasons: ethnic German immigrants tend to vote overwhelmingly for the CDU/CSU, while naturalised immigrants, for instance of Turkish origin, support the SPD and Greens by a comparable margin. ${ }^{78}$ Similarly, the question to what degree dual citizenship should be tolerated in Germany, although latent, remains highly salient; conversely, there is no real prospect of it being politicised in the UK.

\section{Asylum policy}

The third area to be considered, and the one which shows the greatest degree of convergence, has been asylum policy. ${ }^{79}$ In two key respects, convergence in fact took place long before the election of New Labour and the SPD-Green coalition to government: during the 1980s, both the UK and West Germany used visa requirements and carrier sanctions for undocumented immigration to prevent asylum seekers from even being able to lodge a claim in country. Nonetheless, the fact that, for most of the 
1980s and 1990s asylum was a 'German problem' (see above) meant that there was little direct convergence beyond the general desire in both governments to keep claims for asylum as low as possible. However, this changed in the late 1990s with the sharp increase in asylum applications to the UK. Faced with record numbers (and record costs), the UK government drew on a range of ideas first developed in the German context.

First and foremost, in 2000, the UK introduced a formal system of 'dispersal' for asylum seekers, in order to spread their accommodation around the country, as opposed to London and the South East (in particular Kent), which had hitherto borne the brunt of this task. ${ }^{80}$ This instrument drew obvious comparisons with Germany, where the Länder have been allocated fixed proportions of the total number of asylum applications since the late 1970s. Although the two countries' systems of dispersal in fact differ in key respects, ${ }^{81}$ it is the similarity in their aims, a more-or-less formal system of 'burdensharing', which is of relevance here.

Second, and linked to this, the UK in 2000 replaced its cash payments to asylum seekers. Under the new system, asylum seekers received the bulk of their welfare payments via vouchers, which could be used to purchase goods in shops and supermarkets. This too drew on German practices, in which welfare is mostly provided 'in kind', for instance in the form of food parcels, but where some municipalities also use a voucher system. ${ }^{82}$ However, in the UK, the system was heavily criticised for the fact that the retailers would not be required to give change on the vouchers. Unhelpfully for the government, the French company Sodexho, which had run the German version and which was now operating the British scheme, issued promotional literature in which retailers were urged to sign up in order to exploit the 'revenue-making opportunities' 
this presented. ${ }^{83}$ In 2002, the vouchers were dropped for asylum seekers in favour of a return to cash payments, thereby actually marking a divergence from German policy instruments.

Third, the UK has, in the Nationality, Immigration and Asylum Act 2002, introduced a so-called 'White List' of countries from which asylum applications are not accepted. Again, this draws on the 'Safe Country of Origin' category introduced in Germany as early as 1993, although the countries listed notably do not coincide. In Germany, non-European countries on the list are limited to Ghana and Senegal, while the UK in November 2006 considered Brazil, Ecuador, Bolivia, South Africa, India, Jamaica, Mongolia and Sri Lanka to be safe, as well as Ghana and Nigeria for male applicants only.

Overall, then, in those areas where a broad convergence in domestic asylum policy has taken place, the UK has tended to follow, and on occasion even exceed, the German example. Curiously, an almost reverse picture emerges in the case of debates at EU level, due largely to Germany's growing reluctance to integrate further in this policy area. For instance, in the 2004 Qualifications Directive, ${ }^{84}$ Germany finally accepted the principle of recognition of non-state agents of persecution in asylum; hitherto, this question had been one of the most visible and contested elements of divergence between several EU member-states, including the UK and Germany. A second example concerns the processing of asylum seekers: in the run-up to the 2003 European Council meeting in Thessaloniki, the UK proposed that 'regional protection areas' (in areas of origin) and 'transit processing areas' (in neighbouring countries to the EU) be set up, with the aim of preventing asylum seekers from even arriving in the EU. While these proposals were 
roundly rejected by Germany at the time, Interior Minister Otto Schily performed a remarkable volte-face just one year later, by supporting similar Italian proposals. ${ }^{85}$

But the EU has also served as a vehicle for informal cooperation in areas of mutual interest. Key among these has been the sensitive area of the repatriation of failed asylum seekers: in both countries, numbers of removals have been low in recent years, and both countries' governments have grappled with the practical issues surrounding repatriation. ${ }^{86}$ In this context, the Interior Ministers of the UK and Germany, along with their counterparts from France, Italy and Spain, agreed in 2005 to operate joint repatriation flights to countries of origin. In May 2006, this initiative was adopted by all 25 member-states. ${ }^{87}$

As the previous examples show, the extent of convergence, both in the overall policy goals and some of the actual instruments adopted, is considerable, and greater than in labour migration and citizenship and integration policy. This development is certainly linked to the fact that asylum has constituted an explicit common policy challenge to both countries, encouraging common responses. Indeed, the pressures have been such that policy divergence is now effectively limited to individual policy instruments, but not policy goals.

\section{Conclusion}

The preceding analysis has argued that there is notable convergence between the UK and Germany in a number of goals in immigration policy, as well as in a range of specific policy instruments adopted. This convergence is most evident in asylum policy, but also in citizenship policy and, to a lesser extent, labour migration policy. The extent of convergence in this sector is summarised in Table 2. 


\section{- Table 2 about here -}

Most significantly, where convergence has occurred, it has done so despite the very different historical traditions of response to immigration in both countries. It has also done so despite differences in public opinion and differences in the political system, which after all affects the way in which policy goals are articulated and negotiated. This testifies to the strength of the endogenous and exogenous pressures identified - the demographic rationale for new labour migration, the sheer pressures of numbers in the asylum system and the politicisation of integration deficits, real or otherwise. In particular, and despite the UK's de iure opt-in, the EU stands out as a key vehicle towards convergence, especially in the field of asylum policy, where harmonisation is most advanced. The EU has not only acted as a source of policy initiatives in its own right, but has also afforded both countries the opportunity to 'escape to Europe' in seeking solutions to their national asylum problems. In addition, EU membership has as provided a forum for Germany and the UK to coordinate policy instruments, for instance in the context of the G6 group of member-states.

Nonetheless, divergent goals and instruments remain in a number of areas and their persistence can largely be explained historically. This is certainly the case for approaches to integration and family reunification, and arguably labour migration too. Even if overall German unemployment levels were much lower, it is a moot point whether new non-EU labour migration would be tolerated politically and electorally. 
Path dependence thus remains an important factor in understanding particularly policy goals in this field.

Neither this convergence nor the instrumental nature of their relationship with the EU is limited to the UK and Germany. Other EU immigration countries, principally France, the Netherlands, Austria and Sweden share many of the same pressures; they also share at least some of the policy goals and at least some of the policy instruments in at least some of the areas considered here. Indeed, membership of the EU itself represents one of the central pressures towards convergence in a global context. ${ }^{88}$ But equally, it is fair to conclude that, within EU member-states, the UK and Germany show a high degree of convergence across a range of fields.

How much of this is due to the purported ideological closeness of the Labour and SPD-Green governments? Apart from the general and abstract desire to shape labour migration in the respective country's interests, as well as the example of the adoption of the 2000 Race Equality Directive, a common ideological purpose, as put forward in the Third Way document, is difficult to distinguish. Instead, where convergence has taken place, it has generally been in response either to the various pressures outlined here, refracted through the prism of national political priorities.

To conclude, the extent of policy convergence established here is likely to increase in coming years. Not only will the pressures identified above persist in at least the medium term, but the EU is expanding into new areas of activity, as laid down in the 2004 Hague Programme. ${ }^{89}$ One of these is the management of economic migration, on which the Commission already published a Green Paper in $2005 .{ }^{90}$ Therefore, in immigration and integration policy, not only in the UK and Germany but across the EU, convergence appears to be very much the order of the day. 
Table 1: Immigration and Citizenship in the UK and Germany, 2002-2005 (thousands)

\begin{tabular}{l|cccc|cccc}
\hline & \multicolumn{4}{|c}{ UK } & \multicolumn{4}{c}{ Germany } \\
& 2002 & 2003 & 2004 & 2005 & 2002 & 2003 & 2004 & 2005 \\
\hline $\begin{array}{l}\text { Net foreign } \\
\text { immigration }\end{array}$ & 245 & 236 & 342 & 292 & 153 & 103 & 55 & 96 \\
\hline $\begin{array}{l}\text { New asylum } \\
\text { applications }\end{array}$ & 103 & 60 & 40 & 30 & 71 & 51 & 36 & 29 \\
\hline $\begin{array}{l}\text { Total non- } \\
\text { national } \\
\text { population }\end{array}$ & $2,587^{\mathrm{a}}$ & 2,760 & $\mathrm{n} / \mathrm{a}$ & $\mathrm{n} / \mathrm{a}$ & 7,336 & 7,335 & $6,717^{\mathrm{b}}$ & $6,756^{\mathrm{b}}$ \\
\hline Naturalisations & 120 & 126 & 141 & 162 & 155 & 141 & 127 & 117 \\
\hline a 2001 & & & & & & & & \\
\hline
\end{tabular}

${ }^{\mathrm{a}} 2001$

${ }^{\mathrm{b}}$ From 2004, the total is calculated on a different basis to previous years and is therefore not comparable.

Sources: UNHCR, Home Office, Office of National Statistics, Statistisches Bundesamt, Eurostat

\section{Figure 1: Asylum applications in EU-15, 1980-2005}

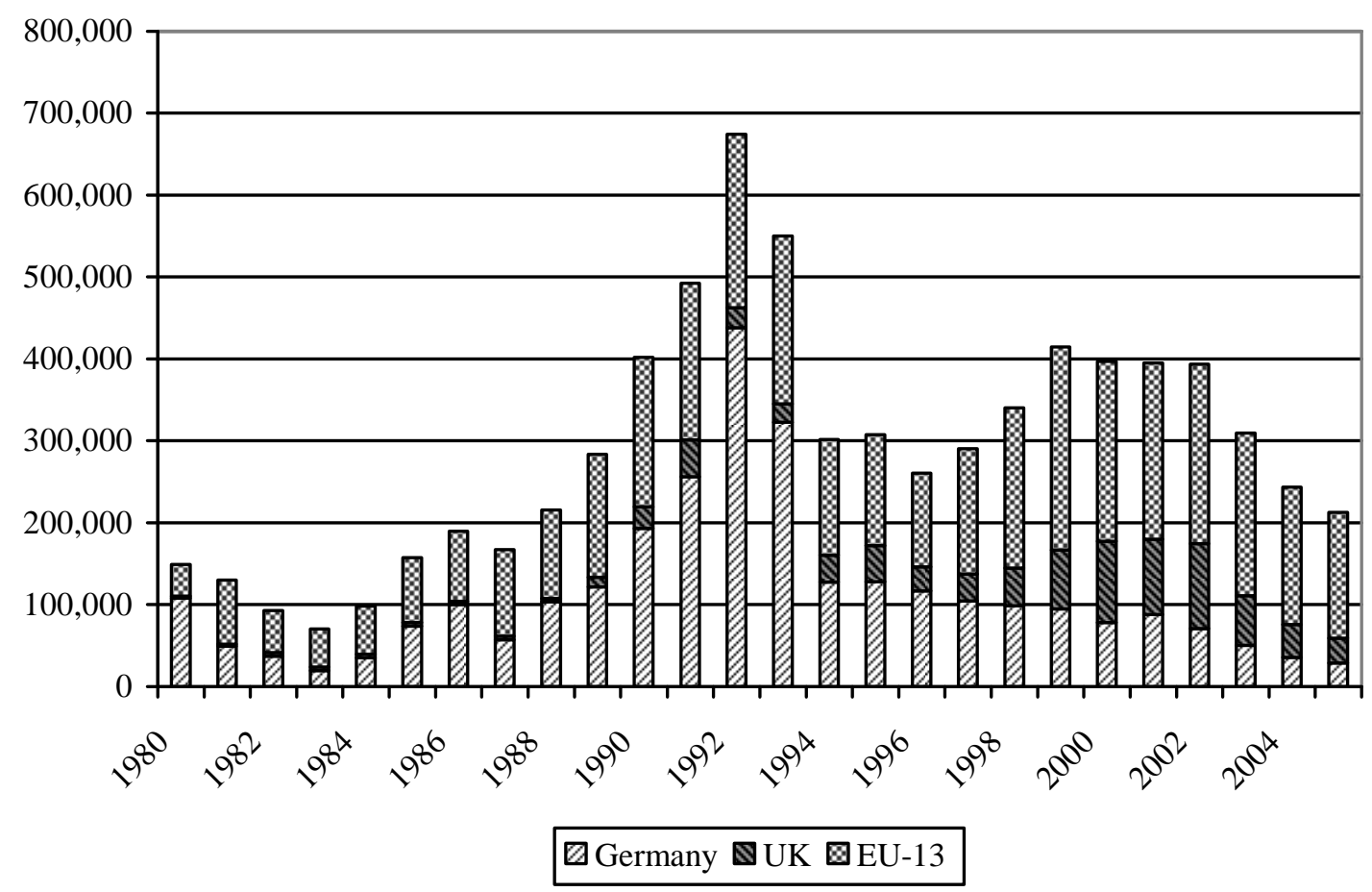

Source: UNHCR

Note: The number of asylum seekers is not the same as asylum applications, as multiple persons can make one application in the UK 
Table 2: Policy convergence in immigration and integration policy

\begin{tabular}{l|ccc}
\hline & $\begin{array}{c}\text { Labour and dependant } \\
\text { migration }\end{array}$ & $\begin{array}{c}\text { Citizenship and } \\
\text { integration }\end{array}$ & Asylum policy \\
\hline $\begin{array}{l}\text { Convergence in } \\
\text { goals }\end{array}$ & Yes & Yes & Yes \\
$\begin{array}{l}\text { Convergence in } \\
\text { instruments }\end{array}$ & No & Partial & Partial \\
$\begin{array}{l}\text { Key aspects of } \\
\text { divergence }\end{array}$ & $\begin{array}{c}\text { Unskilled labour } \\
\text { migration; dependant } \\
\text { migration }\end{array}$ & $\begin{array}{c}\text { Philosophies of } \\
\text { integration; dual } \\
\text { citizenship }\end{array}$ & $\begin{array}{c}\text { Limited to individual } \\
\text { elements }\end{array}$ \\
\hline
\end{tabular}

\section{Notes}

The author would like to thank Insa Nolte, Thomas Saalfeld and Ed Turner for comments on an earlier version of this piece.

${ }^{1}$ See comparative data in Beauftragte der Bundesregierung für Migration, Flüchtlinge und Integration, Daten - Fakten - Trends: Deutschland im Europäischen Vergleich (Berlin, 2005)

${ }^{2}$ Strictly speaking, a differentiation needs to be made between immigrants (i.e. foreign-born residents) and non-nationals (residents without the nationality of their country of residence), where the former term is more common in the UK, and the latter is preferred in Germany.

${ }^{3}$ C. Boswell, European Migration Policies in Flux: Changing Patterns of Inclusion and Exclusion (London / Oxford: RIIA / Blackwell, 2003), pp. 74-5

${ }^{4}$ T. Blair and G. Schröder, Europe: The Third Way, available at: http://www.socialdemocrats.org/blairandschroeder6-8-99.html (accessed 20 September 2006)

${ }^{5}$ D. Flynn, 'New Borders, New Management: The Dilemmas of Modern Immigration Policy', Ethnic and Racial Studies 28/3 (2005), pp. 463-90; S. Green, The Politics of Exclusion: Institutions and Immigration Policy in Contemporary Germany (Manchester: Manchester University Press, 2004), pp. 95-7.

${ }^{6}$ C. Bennett, 'Review Article: What Is Policy Convergence and What Causes It?', British Journal of Political Science 21 (1991), pp. 215-33

${ }^{7}$ G. Peters, Institutional Theory in Political Science: The New Institutionalism (London: Pinter, 1999), p. 63

${ }^{8}$ See for instance R. Brubaker, Citizenship and Nationhood in France and Germany (Cambridge MA: Harvard University Press, 1992); R. Hansen, Citizenship and Immigration in Post-War Britain (Oxford: Oxford University Press, 2000).

${ }^{9}$ Z. Layton-Henry, 'Citizenship and Nationality in Britain', in Z. Layton-Henry and C. Wilpert (eds.), Challenging Racism in Britain and Germany (Basingstoke: Palgrave, 2003)

${ }^{10}$ R. Hansen, 'The Dog that didn't Bark: Dual Nationality in the United Kingdom', in R. Hansen and P. Weil (eds.), Dual Nationality, Social Rights and Federal Citizenship in the US and Europe (Oxford: Berghahn, 2002)

${ }^{11}$ For a magisterial discussion of this process and the politics which surrounded it, see Hansen,

Citizenship and Immigration

${ }^{12}$ See Hansen, Citizenship and Immigration, pp. 250-3

${ }^{13}$ Cf. Boswell, European Migration Policies, pp. 77-9

${ }^{14}$ A. Favell, Philosophies of Integration, $2^{\text {nd }}$ edition (Basingstoke: Palgrave, 2001); see also S. Glover et al., Migration: an Economic and Social Analysis, RDS Occasional Paper No 67 (London: Home Office, 2001)

${ }^{15}$ Cited in Favell, Philosophies of Integration, p. 104

${ }^{16}$ Cf. C. Munro, 'Race Laws and Policy in the United Kingdom', in Layton-Henry and Wilpert, Challenging Racism; see also C. Joppke, Immigration and the Nation-State (Oxford: Oxford University Press, 1999), pp. 223-59

${ }^{17}$ On this era in Germany, see K. Schönwälder, Einwanderung und ethnische Pluralität. Politische Entscheidungen und öffentliche Debatten in Großbritannien und der Bundesrepublik von den 1950er bis zu den 1970er Jahren (Essen: Klartext, 2001); U. Herbert, Geschichte der Ausländerpolitik in 
Deutschland (München: C.H. Beck, 2001), pp. 191-230; J. Motte, R. Ohliger and A. Von Oswald (eds.), 50 Jahre Bundesrepublik: 50 Jahre Einwanderung (Frankfurt a.M.: Campus, 1999)

${ }^{18}$ See D. Bischoff and W. Teubner, Zwischen Einbürgerung und Rückkehr. Ausländerpolitik und Ausländerrecht in der Bundesrepublik Deutschland (Berlin: Hitit Verlag, 1991), pp. 113-17

${ }^{19}$ Cf. Green, The Politics of Exclusion, pp. 31, 84-8

${ }^{20}$ S. Green, 'Immigration and Integration Policy: Between Incrementalism and Non-Decisions', in S. Green and W. Paterson (eds.), Governance in Contemporary Germany: The Semisovereign State Revisited (Cambridge: Cambridge University Press, 2005)

${ }^{21}$ Joppke, Immigration and the Nation State, p. 73

${ }^{22}$ Green, The Politics of Exclusion, pp. 39-41

${ }^{23}$ Cf. D. Klusmeyer, 'A “Guiding Culture” for Immigrants? Integration and Diversity in Germany', Journal of Ethnic and Migration Studies 27/3 (2001), pp. 519-32.

${ }^{24}$ On the question of how the 1913 citizenship law came to form the basis of citizenship in West Germany, see Brubaker, Citizenship and Nationhood, pp. 168-71; also P. Hogwood, 'Citizenship Controversies in Germany: The Twin Legacy of Völkisch Nationalism and the

Alleinvertretungsanspruch', German Politics 9/3 (2000), pp. 125-44

${ }^{25}$ The formulation of the new citizenship law was itself accompanied by one of the most polarised controversies of recent years in Germany, which revolved around the proposed acceptance of dual citizenship. See Green, The Politics of Exclusion, pp. 79-109

${ }^{26}$ Numbers of naturalisations have fallen every year between 2000 (the first year of operation of the new law) and 2005. See S. Green, 'Between Ideology and Pragmatism: The Politics of Dual Nationality in Germany’, International Migration Review 39/4 (2005), pp. 921-52, here pp. 944-6; also S. Green, 'Beyond Ethnoculturalism? German Citizenship in the New Millennium', German Politics 9/3 (2000), pp. 105-24

${ }^{27}$ In which the Conservatives infamously ran campaign posters bearing the slogan 'If you want a nigger neighbour, vote Liberal or Labour'. Quoted in Hansen, Citizenship and Immigration in Post-War Britain, pp. $132-5$

28 'Deutschland: 15 Mio. Einwohner mit "Migrationshintergrund"', Migration und Bevölkerung 5/2006, available at: http://www.migration-info.de/migration_und_bevoelkerung/artikel/060502.htm (accessed 5 September 2006). Persons with 'Migrant background' are defined as those who have migrated themselves, or whose parents or grandparents have migrated to Germany.

${ }^{29}$ S. Green, 'Immigration, Asylum and Citizenship in Germany: The Impact of Unification and the Berlin Republic', West European Politics 24/4 (2001), pp. 82-104

${ }^{30}$ Tony Blair, 'The duty to integrate: Shared British values', 8 December 2006, available via:

http://www.prime-minister.gov.uk/output/Page10563.asp (accessed 8 December 2006)

${ }^{31}$ Although not, it must be noted in relative terms, where smaller EU member-states, especially Belgium, Ireland, Austria and Sweden have much higher levels of applications per 1,000 population than either the UK or Germany. See UNHCR, Asylum levels and trends in industrialized countries 2005 (Geneva: UNHCR, 2006), available via http://www.unhcr.org (accessed 12 September 2006)

${ }^{32}$ C. Boswell, 'European Values and the Asylum Crisis', International Affairs 76/3 (2000), pp. 537-57

${ }^{33}$ Cf. for instance N. Choucri, 'Migration and Security: Some Key Linkages', Journal of International Affairs 56/1 (2002), pp. 97-122; T. Faist, 'Extension du Domaine de la Lutte: International Migration and Security before and after September 11, 2001', International Migration Review 36/1 (2002), pp. 7-14

${ }^{34}$ Cf. J. Huysmans, 'The European Union and the Securitization of Migration', Journal of Common Market Studies 38 (2000), pp. 751-77

${ }^{35}$ See C. Joppke and E. Morawska (eds.), Towards Assimilation and Citizenship (London: Palgrave, 2003)

${ }^{36}$ See Eurostat, Key Figures on Europe: Statistical Pocketbook 2006 (Luxembourg: Office for Official Publications of the European Communities, 2006), p. 43, available at: http://epp.eurostat.ec.europa.eu/cache/ITY_OFFPUB/KS-EI-06-001/EN/KS-EI-06-001-EN.PDF (accessed 12 September 2006)

${ }^{37}$ United Nations Population Division, Replacement Migration: Is it a Solution to Declining and Ageing Populations (New York: United Nations Population Division, 2000), available at:

http://www.un.org/esa/population/publications/migration/migration.htm (accessed 12 September 2006); see also S. Green, 'Immigration to the UK and Germany: A Panacea for Declining Labour Forces?', in. L. Funk and S. Green (eds.), New Aspects of Labour Market Policy (Berlin: Verlag Wissenschaft und Forschung, 2002) 
${ }^{38}$ Animated population pyramids for Germany and the UK, which include assumptions of net immigration, are available, respectively, at http://www.destatis.de/basis/d/bevoe/bev_svg_var.php (accessed 12 September 2006) and http://www.statistics.gov.uk/populationestimates/svg_pyramid/default.htm (accessed 12 September 2006) ${ }^{39}$ Cited in Institute for Public Policy Research, Labour Migration to the UK: An IPPR Factfile (London: IPPR, 2004), p. 12

${ }^{40}$ Deutscher Industrie- und Handelskammertag, Ruhe vor dem Sturm. Arbeitskräftemangel in der Wirtschaft (Berlin: DIHK, 2005), available via:

http://www.dihk.de/inhalt/download/studie arbeitskraeftemangel.pdf (accessed 12 September 2006); cf. A. Reinberg and M. Hummel, 'Fachkräftemangel bedroht Wettbewerbsfähigkeit der deutschen Wirtschaft', Aus Politik und Zeitgeschichte B28/2004, pp. 3-10; also Die Welt (1 December 2006), 'Mittelständler beklagen Fachkräftemangel'

${ }^{41}$ See for instance data in Beauftragte der Bundesregierung für Migration, Flüchtlinge und Integration, 6. Bericht der Beauftragten der Bundesregierung für Migration, Flüchtlinge und Integration zur Lage der Ausländerinnen und Ausländer in Deutschland (Berlin, 2005), available via http://www.bundesregierung.de/Webs/Breg/DE/Bundesregierung/BeauftragtefuerIntegration/Service/serv ice.html (accessed 1 September 2006); OECD, Die Arbeitsmarktintegration von Zuwanderern in Deutschland (Paris: OECD, 2005), available via: http://www.oecd.org/dataoecd/62/12/35796774.pdf (accessed 12 September 2006); R. Berthoud, The Incomes of Ethnic Minorities. ISER Report 98-1 (Colchester: University of Essex, Institute for Social and Economic Research, 1998); G. Bhattacharyya, L. Ison and M Blair, Minority ethnic attainment and participation in education and training: the evidence, Research Topic Paper RTP01 03 (London: DfES, 2003), available via: http://www.dfes.gov.uk/research/data/uploadfiles/RTP01-03.pdf (accessed 12 September 2006) ${ }^{42}$ Beauftragte der Bundesregierung, 6. Bericht; Commission for Racial Equality, Employment and Ethnicity, Factfile 1 (London: CRE, 2006), available via: http://www.cre.gov.uk/downloads/factfile01_employment_and_ethnicity.pdf (accessed 12 September 2006)

${ }^{43}$ J. Monar, 'Justice and Home Affairs: Europeanization as a Government-controlled Process', in. K. Dyson and K. Goetz (eds.), Germany, Europe and the Politics of Constraint, Proceedings of the British Academy 119 (Oxford: Oxford University Press, 2003), p. 309; see also A. Geddes, Immigration and European integration: Towards 'Fortress Europe'? (Manchester: Manchester University Press, 2000) ${ }^{44}$ See for instance Monar, 'Justice and Home Affairs'; S. Lavenex, 'Shifting Up and Out: The Foreign Policy of European Immigration Control', West European Politics 29/2 (2006), pp. 329-50; V. Guiraudon, 'European Integration and Migration policy: Vertical Policy-making as Venue Shopping', Journal of Common Market Studies 38/2 (2000), pp. 251-71; Huysmans, 'The European Union'; V. Guiraudon, 'The Constitution of a European Immigration Policy Domain: A Political Sociology Approach', Journal of European Public Policy 10/2 (2003), pp. 263-82. See also the Introduction to this collection.

${ }^{45}$ UNHCR, Asylum levels and trends in industrialized countries 2005, p. 9. Notably, the highest application rates in EU-15 during this period were in Sweden (14.2 applications per 1,000 population) and Austria (18.2)

${ }^{46}$ Cf. Lavenex, 'Shifting Up and Out', pp. 336-7

${ }^{47}$ Council Directive 2003/86/EC, OJ L 251, 3 October 2003, p. 12 (family reunification); Council Directive 2003/109/EC, OJ L 16, 23 January 2004, p. 44 (long-term resident third country nationals); Council Directive 2004/83/EC, OJ L 304, 30 September 2004, p. 12 (asylum qualifications); Council Directive 2005/85/EC, OJ L 326, 13 December 2005, p. 13 (asylum procedures)

${ }^{48}$ Cf. Article 3 Section 5, Council Directive 2003/86/EC

${ }^{49}$ P. Henson and N. Malhan, 'Endeavours to Export a Migration Crisis: Policy Making and Europeanisation in the German Migration Dilemma', German Politics 4/3 (1995), pp. 128-44

${ }^{50}$ M. Bösche, 'Trapped inside the European Fortress? Germany and the European Union Asylum and Refugee Policy', in G. Hellmann (ed.), Germany's EU policy on Asylum and Defence: DeEuropeanization by default? (London: Palgrave, 2006)

${ }^{51}$ M. Gibney, The Ethics and Politics of Asylum (Cambridge: Cambridge University Press, 2004), p. 129

${ }^{52}$ A. Geddes, 'Getting the Best of Both Worlds? Britain, the EU and Migration Policy', International Affairs 81/4 (2005), pp. 723-40, here pp. 724, 734 
${ }^{53}$ The so-called 'gap hypothesis'; see W. Cornelius and T. Tsuda, 'Controlling Immigration: The Limits of Government Intervention', in W. Cornelius, T. Tsuda, P. Martin and J. Hollifield (eds.), Controlling Immigration: A Global Perspective, $2^{\text {nd }}$ edition (Stanford: Stanford University Press, 2004), pp. 4-15

${ }^{54}$ A. Caviedes, 'The Social Partners and the Changing Face of German and British Labor Migration Policy', paper presented at the annual conference of the American Political Science Association, Washington DC, 1-4 September 2005.

${ }^{55}$ Cf. H. Kolb, 'Die Green Card: Inszenierung eines Politikwechsels', Aus Politik und Zeitgeschichte B27/2005, pp. 18-24

${ }^{56}$ Green, The Politics of Exclusion, pp. 110-32

${ }^{57}$ Beauftragte der Bundesregierung, 6. Bericht, pp. 81-2

${ }^{58}$ See Der Spiegel (2 September 2002), “Lasst uns hier abhauen”, pp. 138-42

59 'Deutschland: Debatte um Zuwanderung von Fachkräften', Migration und Bevölkerung 7/2006, available at: http://www.migration-info.de/migration_und bevoelkerung/artikel/060704.htm (accessed 5 September 2006)

${ }^{60}$ Boswell, European Migration Policies, pp. 37-40

${ }^{61} \mathrm{Cf}$. IPPR, Labour Migration to the UK, pp. 7-11

${ }^{62}$ See 'Immigration and the Labour Market: Demand, Recruitment and Integration', Search for Solutions Briefing Paper No. 2 (Birmingham: University of Birmingham, 2004), available via:

http://www.igs.bham.ac.uk/searchforsolutions/Immigration\%20Briefing\%20Paper.pdf (accessed 3 June 2006)

${ }^{63}$ Home Office, Controlling our Borders: Making Migration Work for Britain, CM 6472 (London: HMSO, 2005)

${ }^{64}$ Home Office, Department for Work and Pensions, HM Revenue and Customs and Department for Communities and Local Government, Accession Monitoring Report May 2004 - June 2006 (22 August 2006), available at: http://www.ind.homeoffice.gov.uk/6353/aboutus/Revised_data_MT.final.pdf (accessed 12 September 2006)

${ }^{65}$ For a discussion of this area, especially in the UK, see E. Kofman, 'Family-related Migration: A Critical Review of European Studies', Journal of Ethnic and Migration Studies 30/2 (2004), pp. 243-62

${ }^{66}$ K. Hailbronner, 'Reform des Zuwanderungsrechts. Konsens und Dissens in der Ausländerpolitik', Aus Politik und Zeitgeschichte B43/2001, pp. 7-19, here pp. 12-14

${ }^{67}$ R. Brubaker, 'The Return of Assimilation', Ethnic and Racial Studies 24/4 (2001), pp. 531-48

${ }^{68}$ R. Hansen and P. Weil (eds.), Towards a European Nationality? Citizenship, Immigration and Nationality Law in the EU (London: Palgrave, 2001)

${ }^{69}$ The substantive basis of UK citizenship tests is outlined in Home Office, Life in the United Kingdom: A Journey to Citizenship (London: The Stationery Office, 2004)

70 'Deutschland: Neue Einbürgerungsrichtlinien', Migration und Bevölkerung 5/2006, available at: http://www.migration-info.de/migration_und_bevoelkerung/artikel/060503.htm (accessed 12 September 2006)

${ }^{71}$ Blair, 'The duty to integrate'

${ }^{72}$ C. Joppke, 'Beyond National Models: Civic Integration Policies for Immigrants in Western Europe', West European Politics 30/1 (2007), pp. 1-22

${ }^{73}$ Racial Equality Directive: Council Directive 2000/43/EC, OJ L 180, 19 July 2000, p. 22; Employment Equality Directive: Council Directive 2000/78/EC, OJ L 303, 2 December 2000, p. 16

${ }^{74}$ A. Geddes and V. Guiraudon, 'Britain, France and EU Anti-discrimination Policy: The Emergence of an EU Policy Paradigm', West European Politics 27/2 (2004), pp. 334-53

75 'Aufbruch und Erneuerung - Deutschlands Weg ins 21. Jahrhundert. Koalitionsvereinbarung zwischen der Sozialdemokratischen Partei Deutschlands und Bündnis 90/Die Grünen' (Bonn, 20 October 1998), Article 9; available at: http://www.datenschutz-berlin.de/doc/de/koalo/index.htm (accessed 1 October 2006)

${ }^{76}$ Geddes and Guiraudon, 'Britain, France and EU Anti-discrimination Policy', pp. 346-7

${ }^{77}$ This therefore echoes Andrew Moravcsik's explanation of the formulation of the Single European Act. See A. Moravcsik, The Choice for Europe: Social Purpose and State Power from Messina to Maastricht (London: Routledge, 1998)

${ }^{78}$ A. Wüst, 'Das Wahlverhalten eingebürgerte Personen in Deutschland', Aus Politik und Zeitgeschichte B52/2003, pp. 29-38

${ }^{79}$ For a general discussion of this area in a British-German context, see L. Schuster, The Use and Abuse of Political Asylum in Britain and Germany (Southgate: Taylor and Francis, 2003) 
${ }^{80}$ In fact, dispersal of immigrants had been practised previously, albeit intermittently and on a much smaller scale. See V. Robinson, 'Dispersal policies in the UK', in V. Robinson, R. Andersson and S. Musterd (eds.), Spreading the 'Burden'? A Review of Policies to Disperse Asylum Seekers and Refugees (Bristol: The Policy Press, 2003)

${ }^{81}$ C. Boswell, 'Burden-sharing in the European Union: Lessons from the German and UK Experience', Journal of Refugee Studies 16/3 (2003), pp. 316-335

${ }^{82}$ C. Boswell, Spreading the Costs of Asylum Seekers: A Critical Assessment of Dispersal Policies in Germany and the UK (London: Anglo-German Foundation), p. 21, available via: http://www.agf.org.uk/pubs/pdfs/r1314e.pdf (accessed 12 June 2006)

${ }^{83}$ The Guardian (10 March 2000), 'Keep the change, refugee voucher stores are told'

${ }^{84}$ Council Directive 2004/83/EC

${ }^{85}$ See 'EU: Entwicklungen in der Asyl- und Einwanderungspolitik', Migration und Bevölkerung 6/2003, available at: http://www.migration-info.de/migration_und bevoelkerung/artikel/030607.htm (accessed 5 September 2006); also 'Deutschland: Schily schlägt Asyllager in Afrika vor', Migration und Bevölkerung 7/2004, available at: http://www.migration-info.de/migration_und_bevoelkerung/artikel/040701.htm (accessed 5 September 2006)

${ }^{86}$ Cf. C. Phuong, 'The Removal of Failed Asylum Seekers', Legal Studies 25/1 (2005), pp. 117-41; M. Gibney and R. Hansen, Deportation and the Liberal State: The Forcible Return of Asylum Seekers and Unlawful Migrants in Canada, Germany and the United Kingdom, UNHCR New Issues in Refugee Research Working Paper No. 77 (Geneva: UNHCR, 2003); Der Spiegel (6 November 2000), 'Alias aus Angeblichstan', pp. 72-85. See also National Audit Office, Returning Failed Asylum Applicants, HC76 (London: The Stationery Office, 2005), which explicitly draws on the German experience of this issue. 87 'EU: Gemeinsame Abschiebungen und Anhebung der Visa-Gebühren', Migration und Bevölkerung 4/2006, available at: http://www.migration-info.de/migration_und_bevoelkerung/artikel/060406.htm (accessed 12 September 2006)

${ }^{88}$ Cornelius and Tsuda, 'Controlling immigration', p. 18

${ }^{89} \mathrm{COM}(2005) 184$ final

${ }^{90} \mathrm{COM}(2004) 811$ final 